\title{
Sharp genetic break between Atlantic and English Channel populations of the polychaete Pectinaria koreni, along the North coast of France
}

\author{
MT Jolly ${ }^{1}$, D Jollivet ${ }^{1}$, F Gentil ${ }^{2}$, E Thiébaut ${ }^{3}$ and F Viard ${ }^{1}$ \\ ${ }^{1}$ Evolution et Génétique des Populations Marines, Station Biologique de Roscoff, CNRS-UPMC, UMR 7127, B.P. 74, 29682, Roscoff, \\ France; ${ }^{2}$ Ecologie Benthique, Station Biologique de Roscoff, CNRS-UPMC, UMR 7127, Roscoff, France; ${ }^{3}$ Biologie des Organismes \\ Marins et Ecosystèmes, CNRS-MNHN-UPMC, UMR 5178, Département Milieux et Peuplements Aquatiques, Muséum National \\ d'Histoire Naturelle, 61 rue Buffon, Paris 75005, France
}

\begin{abstract}
This study uses enzymatic and mitochondrial genes to infer the relative importance of historical processes and contemporary hydrodynamic features on the observed patterns of genetic structure in subdivided populations of Pectinaria koreni (Polychaeta: Pectinariidae) along the coasts of Brittany and the English Channel. Nucleotide sequence variation of a 603-bp fragment of the mtDNA cytochrome oxidase subunit I gene revealed a surprisingly deep phylogeographic break of about $16 \%$ divergence separating the Brittany and Channel populations, which coincides with a biogeographic boundary along the western coast of Brittany. Deep sequence divergence with fixed haplotype differences and the inversion of allele frequencies at two enzyme loci suggests the occurrence of potential cryptic or sibling
\end{abstract}

species of $P$. koreni. The two clades showed opposite features. Channel populations exhibited bimodal matchmismatch curves due to two highly divergent haplotypes occurring at high frequencies and no overall heterozygote deficiencies at enzyme loci, suggesting respectively, a historic secondary contact between two differentiated populations followed by contemporary panmixia. On the contrary, Brittany populations displayed unimodal curves with low nucleotide diversity and highly significant heterozygote deficiencies, probably reminiscent of a recent population expansion and recolonisation of Brittany with contemporary admixture of divergent populations.

Heredity (2005) 94, 23-32. doi:10.1038/sj.hdy.6800543

Published online 11 August 2004

Keywords: phylogeography; allozymes; mtDNA; parapatric boundary; cryptic species

\section{Introduction}

Marine biogeographic boundaries are transition zones of significant ecological complexity (ie because of overlaps in faunal assemblages; see Holt and Keitt, 2000 for biological complexities arising from species range limits) and important in terms of evolutionary processes (ie mating isolation, maintenance of hybrid zones, speciation). Such boundaries may give rise to biogeographic barriers, which are filters for many species depending on their ability to disperse, reproduce and survive various environmental conditions and the level of habitat fragmentation, potentially leading to differences in the genetic structure of populations on either side. Studies of allozymes and/or mitochondrial DNA divergence in invertebrate species living across such barriers have revealed major phylogeographic breaks concordant with biogeographic boundaries, plate movements and contemporary oceanographic conditions, which may act to maintain or not such breaks (Crassostrea virginica, Reeb and Avise, 1990; Tigriopus californicus, Burton, 1998; Linkia laevigata, Williams and Benzie, 1998; Streblospio spp,

Correspondence: MT Jolly, Evolution et Génétique des Populations Marines, Station Biologique de Roscoff, CNRS-UPMC, UMR 7127, B.P. 74, 29682 Roscoff cedex, France. E-mail: jolly@sb-roscoff.fr Received 1 October 2003; accepted 2 June 2004; published online 11 August 2004
Schulze et al, 2000; Perna canaliculus, Apte and Gardner, 2002).

The Iroise Sea and the north western part of the Brittany coast (France), is a biogeographic transition zone between temperate and cold-temperate/boreal marine faunal assemblages (Cox and Moore, 2000; Dinter, 2001). Unlike the Cap Canaveral (East coast of Florida) and Point Conception (California) boundaries, the North west coast of Brittany has been less studied in terms of phylogeographic structure, despite some interesting dynamic features revealed by the modelling of longterm currents in the English Channel (Salomon and Breton, 1993). An inflow of warmer/higher salinity water derived from the North-Atlantic drift enters the western English Channel along the north coast of Brittany, thereby facilitating larval export from the south to the north coast. However, in the case of the shallow-water gastropod Hydrobia sp, the ecological conditions specific to each biogeographical region seem to have prevented dispersal across most of the north coast of Brittany, thus leading to strong spatial isolation between Hydrobia glyca and $H$. acuta neglecta (Wilke and Pfenninger, 2002). This water then circles northwards to return to the Celtic Sea along the south coast of Cornwall. Some of this water also passes north-eastwards on the English side of the Channel (see Beaumont, 1982 and references within). A frontal system known as the Ushant front develops between north Brittany and the tip of Cornwall in 
summer at the confluence of mixed and stratified waters, west of $5^{\circ} \mathrm{W}$ (Pingree et al, 1975). Structures such as eddies (ie circular currents) may promote the isolation of populations and are constrained locally along both coasts of the Channel (Salomon and Breton, 1993). Finally, a strongly oriented west-east current separates (1) the eastern from the western province of the English Channel, at the Wight-Cotentin section and (2) the English and French coasts in the eastern province, between Cherbourg and the straights of Dover.

Genetic studies of Atlantic and English Channel populations of invertebrates have mostly concerned commercially exploited or invasive species (for example, Mytilus sp, Bierne et al, 2003; Aequipecten (Chlamys) opercularis, Beaumont et al, 1982; O. edulis, Saavedra et al, 1995; Pecten maximus, Wilding et al, 1997; Crepidula fornicata, Dupont et al, 2003). However, the impact of human activities interferes with the study of natural evolutionary processes by reinforcing secondary contacts between previously isolated populations. To infer historical processes that have led to present patterns of genetic structure in Atlantic and English Channel populations of marine invertebrates, it is necessary to study native species with a large distribution and presenting a number of populations throughout their range. The tubeworm Pectinaria koreni (Malmgren) is a polychaete species with nonoverlapping generations that presents all these characteristics. It belongs to the Atlantic boreal fauna and is widely distributed along the European coastlines from Scandinavia to the Mediterranean Sea (Holthe, 1978). In addition, the species possesses a bentho-pelagic lifecycle (ie a benthic reproducing adult stage and a 15-day dispersive larval stage) representative of most of the commercially exploited invertebrates, but is not itself exploited. P. koreni is a gonochoric species (sex ratio 1:1) and has a main breeding period occurring between March and July, with the release of 20000430000 oocytes per female (Irlinger et al, 1991). As populations are confined to muddy-fine sediments (necessary to construct their tube) in shallow waters of bays and estuaries, the species thereby exhibits a highly fragmented distribution along its range.

This study uses polymorphic enzymatic and mitochondrial genes in 12 populations of $P$. koreni sampled along both coasts of the English Channel and southern Brittany, to infer the relative importance of historical processes and contemporary hydrodynamic features on the observed patterns of genetic structure. Owing to the very high levels of sequence polymorphism in $P$. koreni (Weinmayr, 1999), microsatellites were found mainly to reflect contemporary gene flow and thus were not appropriate to infer possible phylogeographic breaks between populations. On the contrary, allozyme markers (six loci screened across 306 individuals sampled within the seven most representative populations) and a partial fragment of the mitochondrial cytochrome oxidase submit I (COI) gene (206 individuals sampled in 12 populations) were found polymorphic and divergent enough to test the hypothesis of a genetic break across the Iroise transition zone between populations of $P$. koreni.

\section{Material and methods}

\section{Sampling sites}

Samples of $P$. koreni were obtained by sampling the top $10 \mathrm{~cm}$ of the sediment with a $0.25 \mathrm{~m}^{-2}$ Hamon grab or, in some cases where individuals were scarce, by dredging. Populations from bays and estuaries along both coasts of the English Channel were sampled during the 2000 PECTGENE cruise on board the 'NO Côte de la Manche'. Additional populations of the Baie du Mont $\mathrm{S}^{\mathrm{T}}$ Michel and Morgat were sampled by foot during the lowest tides in April 2001. Samples from Morlaix Bay were gathered over a 2-year period as only one to two individuals were collected each time. It therefore seems that this site is not representative of a truly established population. Finally, the Lorient and Concarneau populations on the south coast of Brittany were sampled in April 2002 on board the 'NO Côte d'Aquitaine'. After sampling, the individuals were kept in liquid nitrogen until DNA and protein extractions. Table 1 shows the location of the populations sampled along the coast of Brittany and the English Channel.

\section{Allozyme electrophoresis}

Horizontal enzyme electrophoresis was conducted on $12 \%$ starch gels and electrophoretic procedures were performed according to the methods of Pasteur et al (1987). Depending on the size of the animals, frozen samples of a whole or of a piece of body (cephalic disk and gills) were each macerated with 60-100 $\mu \mathrm{l}$ of grinding buffer $(0.05 \mathrm{M}$ Tris $/ \mathrm{HCl}, \mathrm{pH} 8.0)$, prior to centrifugation at $15000 \mathrm{rpm}$ for $5 \mathrm{~min}$. The supernatant was then absorbed onto $4 \mathrm{~mm} \times 12 \mathrm{~mm}$ filter-paper wicks

Table 1 Names (abbreviations) and locations of the P. koreni populations sampled along the coasts of Brittany and the English Channel

\begin{tabular}{|c|c|c|c|c|}
\hline Population names & Latitude & Longitude & $\mathrm{N}_{\text {ALLOZYMES }}$ & $\mathrm{N}_{\mathrm{COI}}$ \\
\hline Great Western Bay (GWB) & $50^{\circ} 18.50^{\prime} \mathrm{N}$ & $3^{\circ} 25.00^{\prime} \mathrm{W}$ & - & 14 \\
\hline Beachy Head $(\mathrm{BH})$ & $50^{\circ} 46.00^{\prime} \mathrm{N}$ & $0^{\circ} 01.60^{\prime} \mathrm{E}$ & - & 12 \\
\hline Rye Bay (RB) & $50^{\circ} 53.73^{\prime} \mathrm{N}$ & $0^{\circ} 53.75^{\prime} \mathrm{E}$ & 50 & 25 \\
\hline Gravelines (GR) & $51^{\circ} 01.40^{\prime} \mathrm{N}$ & $2^{\circ} 04.70^{\prime} \mathrm{E}$ & 50 & 21 \\
\hline Pays de Caux (PC) & $50^{\circ} 24.20^{\prime} \mathrm{N}$ & $1^{\circ} 31.60^{\prime} \mathrm{E}$ & - & 13 \\
\hline Baie de Seine (BS) & $49^{\circ} 27.20^{\prime} \mathrm{N}$ & $0^{\circ} 01.50^{\prime} \mathrm{E}$ & 47 & 25 \\
\hline Baie des Veys (BV) & $49^{\circ} 32.00^{\prime} \mathrm{N}$ & $1^{\circ} 15.50^{\prime} \mathrm{W}$ & - & 22 \\
\hline Mont ST Michel (MSM) & $48^{\circ} 03.82^{\prime} \mathrm{N}$ & $1^{\circ} 33.00^{\prime} \mathrm{W}$ & 27 & 15 \\
\hline Morlaix (MRL) & $48^{\circ} 42.83^{\prime} \mathrm{N}$ & $3^{\circ} 52.62^{\prime} \mathrm{W}$ & - & 7 \\
\hline Morgat (MO) & $48^{\circ} 15.00^{\prime} \mathrm{N}$ & $4^{\circ} 30.00^{\prime} \mathrm{W}$ & 50 & 26 \\
\hline Concarneau (CC) & $49^{\circ} 51.50^{\prime} \mathrm{N}$ & $3^{\circ} 57.50^{\prime} \mathrm{W}$ & 32 & 8 \\
\hline Lorient (LO) & $47^{\circ} 43.28^{\prime} \mathrm{N}$ & $3^{\circ} 21.94^{\prime} \mathrm{W}$ & 50 & 18 \\
\hline
\end{tabular}

$N$ is the number of individuals analysed using allozymes and a 603-bp mtDNA COI fragment. 
(Whatman No. 1) and electrophoresed using the following buffers: (1) Tris-borate-EDTA (TBE), $\mathrm{pH} 8$ for mannose phosphate isomerase (Mpi, E.C. 5.3.1.8), phosphoglucomutase (Pgm, E.C. 5.4.2.2) and phosphoglucose isomerase (Pgi, E.C. 5.3.1.9); (2) Tris-citric-boric-lithium hydroxide ( $\mathrm{LiOH})$, electrodes $\mathrm{pH} 8.29$, gel $\mathrm{pH} 8.26$, for Lamino peptidase (Lap, E.C. 3.4.11.1), malic enzyme ( $\mathrm{Me}$, E.C. 1.1.1.40); (3) Tris-citrate (TC), electrodes pH 6.3, gel $\mathrm{pH}$ 6.7, for malate dehydrogenase (Mdh, E.C. 1.1.1.37). Buffer systems (1) and (2) were run at $150 \mathrm{~V}, 80 \mathrm{~mA}$ for $6 \mathrm{~h}$ and buffer system (3) at $100 \mathrm{~V}, 60 \mathrm{~mA}$ for $6 \mathrm{~h}$; all at $4^{\circ} \mathrm{C}$. Amperage was maintained constant and all six enzyme systems (six loci) were visualised using enzymespecific stains according to Pasteur et al (1987).

\section{Mitochondrial COI sequencing of PCR products}

Total genomic DNA was extracted according to the extraction method given in Jolly et al (2003). Partial sequences $(710 \mathrm{bp})$ of the mitochondrial COI gene were amplified with the universally applicable primers described by Folmer et al (1994), following the author's PCR conditions, but with an annealing temperature of $50^{\circ} \mathrm{C}$. However, PCR reactions were performed into a $26 \mu \mathrm{l}$ reaction volume consisting of $1 \times \mathrm{PCR}$ buffer (supplied with polymerase enzyme), $2 \mathrm{mM} \mathrm{MgCl}, 0.12 \mathrm{mM} \mathrm{dNTP}$, $0.2 \mu \mathrm{M}$ of forward and reverse primers, $0.5 \mathrm{U}$ of Thermoprime Plus Taq polymerase (ABgene), 25-50 ng CTABextracted genomic DNA. The PCR products were then purified and sequenced on ABI 3100 using BigDye ${ }^{\odot}$ (Perkin-Elmer) terminator chemistry, following the manufacturer's protocol. Forward and reverse sequences were proofread in Chromas 2.23 and aligned manually in BioEdit Sequence Alignment Editor (Hall, 1999).

\section{Statistical analyses}

Allozymes: For each population, allele frequencies, mean number of alleles per population $\left(N_{\mathrm{ALL}}\right)$, observed $\left(H_{0}\right)$ and expected heterozygosity $\left(H_{\mathrm{NB}} ; \mathrm{Nei}\right.$, 1987) were estimated using GENEPOP 3.3. software (Raymond and Rousset, 1995) and Fstat 2.9 (Goudet, $1995)$ was used to estimate allelic richness $\left(R_{S}\right)$. The null hypothesis of independence between loci was tested from genotypic disequilibrium analysis and isolation-bydistance was tested with a Mantel test. Deviations from Hardy-Weinberg equilibrium were examined for each population, at each locus, by calculating Wright's fixation index $F_{\text {IS }}$ as estimated by Weir and Cockerham (1984) $f$, which was then tested using exact tests. Overall levels of genetic differentiation was analysed by calculating the estimator $\hat{\theta}$ of Wright's $\mathrm{F}_{\mathrm{ST}}$ statistic for each locus, and tested using exact tests for the null hypothesis of identity of allelic distribution across populations. Multilocus $\hat{\theta}$ values were also calculated between pairwise combinations of populations. All the above analyses were performed using GENEPOP 3.3 (Raymond and Rousset, 1995). Group comparisons were used to test for regional structure between populations of the Brittany coast and the English Channel using Fstat 2.9 (Goudet, 1995) and a analysis of molecular variance (AMOVA) analysis between groups was performed using ARLEQUIN vs 2 (Schneider et al, 2000). The relationships between Atlantic and English Channel populations were illustrated by a tree based on
UPGMA clustering of Reynolds et al (1983) distance using the POPULATION 1.2.28 software (Langella, 2002).

Mitochondrial DNA: For each population, haplotype diversity $\left(h_{\mathrm{e}-\mathrm{HAP}}\right)$ and nucleotide diversity $(\pi)$ were examined with DnaSP vs 3 (Rozas \& Rozas, 1999) and match-mismatch curves for all populations were created using the same program. In addition, Tajima's $D$ statistic (Tajima, 1989) was investigated as an index of departure from population equilibrium. To analyse the relationships between Atlantic and English Channel populations, a neighbour-joining tree was constructed (using all informative sites) based on Kimura-2 parameter (Kimura, 1980), with MEGA vs 2.1 (Kumar et al, 2001), with 1000 resampling of the data set (bootstraps) and with $P$. auricoma as outgroup. The same software was used to test for the relative rate constancy of a molecular clock. Estimates of the time of divergence $(T)$ between Atlantic and English Channel population clusters was carried out by computing the average distance $\left(D_{\mathrm{AVG}}\right)$ and standard error between clusters according to the Kimura-2 parameter model (Kimura, 1980) with MEGA vs 2.1 (Kumar et al, 2001) and estimating $T$ according to specific mutation rate of the mtCOI (see Chevaldonné et al, 2002). An AMOVA analysis of variance between groups and populations was performed using ARLEQUIN vs 2 (Schneider et al, 2000). Minimum-spanning networks were created using TCS vs 1.13 (Clement et al, 2000) to infer the most parsimonious branch connections between the sampled haplotypes among (1) the English Channel populations and (2) the Brittany populations.

\section{Results}

\section{Allozymes}

Six enzyme loci were found polymorphic and average genetic diversity $\left(H_{\mathrm{NB}}\right)$ for polymorphic loci was $44.8 \%$. No genotypic disequilibrium was detected, indicating that loci give independent information. Despite no isolation-by-distance at the scale of our study (Mantel test $P$-value $=0.162$ ), the distribution of allelic frequencies across populations (Table 2) suggests the existence of a pronounced cline at the Pgi locus for both Pgi-97 and Pgi-100, with an inversion of allele frequencies in Lorient. Clinal variation was also observed at the $M d h$ locus ( $M d h$ 93 and $M d h$ 100) together with a slight inversion of Mpi100 for Mpi-95 in all three populations of Brittany. Rare alleles were found not only in the highly polymorphic Mpi enzyme (Mpi 77 and 106) but also at the Lap locus (Lap 104) and at the Mdh locus (Mdh 114). The latter locus was found monomorphic only in the Mont Saint Michel population. This can be explained by a lower sample size at this site $(N=27)$ as this population was also characterised by a lower allelic richness $\left(R_{\mathrm{S}}=2.675\right)$ (Table 3). There were also significant differences $(P<0.04)$ in both allelic richness $\left(R_{\mathrm{S}}\right)$ and gene diversity $\left(H_{\mathrm{S}}\right)$ between the 'Brittany' $\left(R_{\mathrm{S}}=3.174 ; H_{\mathrm{S}}=0.503\right)$ and the 'English Channel' groups $\left(R_{\mathrm{S}}=2.907 ; H_{\mathrm{S}}=0.398\right)$. Except for Gravelines, no significant deviations from Hardy-Weinberg expectations were recorded within the English Channel populations or in the Mont Saint Michel (Table 4). On the contrary, all three Brittany populations showed highly significant $F_{\text {IS }}$ values at least three loci 
Table 2 P koreni. Allele frequencies (a denotes a rare allele) and sample size $(N)$ at each site

\begin{tabular}{|c|c|c|c|c|c|c|c|c|}
\hline $\begin{array}{l}\mathrm{N} \\
\text { Locus } \\
\text { Allele }\end{array}$ & $\begin{array}{c}\text { Rye Bay } \\
50\end{array}$ & $\begin{array}{l}\text { Gravelines } \\
50\end{array}$ & $\begin{array}{c}\text { Baie de Seine } \\
47\end{array}$ & $\begin{array}{c}\text { Mont } S^{T} \text { Michel } \\
27\end{array}$ & $\begin{array}{c}\text { Morgat } \\
50\end{array}$ & $\begin{array}{c}\text { Concarneau } \\
32\end{array}$ & $\begin{array}{l}\text { Lorient } \\
\quad 50\end{array}$ & $\underline{\text { All }}$ \\
\hline \multicolumn{9}{|l|}{ Lap } \\
\hline 94 & 0.080 & 0.150 & 0.096 & 0.200 & 0.228 & 0.167 & 0.076 & 0.142 \\
\hline 100 & 0.890 & 0.840 & 0.851 & 0.760 & 0.739 & 0.817 & 0.902 & 0.828 \\
\hline $104^{\mathrm{a}}$ & 0.030 & 0.010 & 0.053 & 0.040 & 0.033 & 0.017 & 0.022 & 0.029 \\
\hline \multicolumn{9}{|l|}{$M d h$} \\
\hline 93 & 0.050 & 0.136 & 0.044 & 0.000 & 0.061 & 0.300 & 0.205 & 0.114 \\
\hline 100 & 0.910 & 0.830 & 0.933 & 1.000 & 0.829 & 0.520 & 0.682 & 0.815 \\
\hline 107 & 0.030 & 0.034 & 0.011 & 0.000 & 0.098 & 0.060 & 0.091 & 0.046 \\
\hline $114^{\mathrm{a}}$ & 0.010 & 0.000 & 0.011 & 0.000 & 0.012 & 0.120 & 0.023 & 0.025 \\
\hline \multicolumn{9}{|l|}{$M e$} \\
\hline 90 & 0.160 & 0.122 & 0.083 & 0.039 & 0.133 & 0.205 & 0.222 & 0.138 \\
\hline 100 & 0.740 & 0.743 & 0.798 & 0.846 & 0.733 & 0.659 & 0.681 & 0.743 \\
\hline 105 & 0.100 & 0.135 & 0.119 & 0.115 & 0.133 & 0.136 & 0.097 & 0.119 \\
\hline \multicolumn{9}{|l|}{ Mpi } \\
\hline $77^{a}$ & 0.032 & 0.000 & 0.023 & 0.019 & 0.000 & 0.048 & 0.000 & 0.017 \\
\hline 88 & 0.053 & 0.030 & 0.023 & 0.056 & 0.020 & 0.081 & 0.082 & 0.049 \\
\hline 93 & 0.117 & 0.070 & 0.102 & 0.093 & 0.080 & 0.145 & 0.184 & 0.113 \\
\hline 95 & 0.202 & 0.330 & 0.273 & 0.315 & 0.400 & 0.242 & 0.316 & 0.297 \\
\hline 100 & 0.383 & 0.400 & 0.455 & 0.333 & 0.370 & 0.242 & 0.276 & 0.351 \\
\hline 104 & 0.202 & 0.150 & 0.125 & 0.148 & 0.110 & 0.226 & 0.112 & 0.153 \\
\hline $106^{\mathrm{a}}$ & 0.011 & 0.020 & 0.000 & 0.037 & 0.020 & 0.016 & 0.031 & 0.019 \\
\hline \multicolumn{9}{|l|}{$P g i$} \\
\hline 97 & 0.071 & 0.011 & 0.172 & 0.125 & 0.190 & 0.323 & 0.670 & 0.223 \\
\hline 100 & 0.714 & 0.913 & 0.641 & 0.833 & 0.730 & 0.613 & 0.320 & 0.681 \\
\hline 106 & 0.214 & 0.076 & 0.188 & 0.042 & 0.080 & 0.065 & 0.010 & 0.193 \\
\hline \multicolumn{9}{|l|}{ Pgm } \\
\hline 91 & 0.044 & 0.063 & 0.090 & 0.022 & 0.023 & 0.241 & 0.095 & 0.083 \\
\hline 94 & 0.211 & 0.125 & 0.256 & 0.413 & 0.216 & 0.407 & 0.250 & 0.268 \\
\hline 100 & 0.700 & 0.688 & 0.577 & 0.565 & 0.636 & 0.315 & 0.631 & 0.587 \\
\hline 106 & 0.044 & 0.125 & 0.077 & 0.000 & 0.125 & 0.037 & 0.024 & 0.062 \\
\hline
\end{tabular}

(Me, Mpi and Pgi). Large heterozygote deficiencies were reflected in another two loci (Mdh and $P g m)$ in Concarneau, and in the Pgm loci in Lorient. This result is possibly associated either with the co-occurrence of highly differentiated groups of individuals (Walhund effect) or with a high level of inbreeding. The AMOVA analysis of variance (Table 5) chosen to test for regional structure between populations of the English Channel and Brittany revealed a significant level of genetic heterogeneity among the two groups $\left(\mathrm{F}_{\mathrm{CT}}=0.029\right.$; $P=0.032$ ), but which only accounted for $0.18 \%$ of the total variance. As a comparison, variation among populations within groups was $0.95 \% \quad\left(\mathrm{~F}_{\mathrm{SC}}=0.043\right.$; $\left.P<10^{-4}\right)$. Pairwise values of genetic differentiation (Table 6) indicated the isolation of the three populations present along the coast of Brittany (Concarneau, Lorient and to a lesser extent Morgat), while within the English Channel, Gravelines was the only population that appeared genetically isolated from all others except with Rye Bay. These pairwise values of differentiation are illustrated in the UPGMA tree (Figure 1) which showed a major genetic split between the Atlantic (Concarneau, Lorient) and the English Channel populations, with Morgat closely related to the latter group but with low bootstrap value. Removal of the above population slightly improves bootstrap values.

\section{mtCOI}

The individuals were screened for variation from a 603bp partial mitochondrial COI sequence, and a total of 81 haplotypes were detected that revealed 122 polymorphic sites. Of these variable sites, $80 \%$ were parsimoniously informative and $20 \%$ were singletons. Transition/transversion ratio was 2.76 and total haplotype $\left(h_{\mathrm{e}-\mathrm{HAP}}\right)$ and nucleotide diversity $(\pi)$ were $0.926 \pm 0.011$ and $0.0619 \pm 0.008$, respectively. Genetic variation for all populations is indicated in Table 3. The individuals from Morlaix (MRL) exhibited the lowest haplotype diversity and the highest nucleotide diversity, but which was due to the presence of only one individual exhibiting a highly divergent haplotype characteristic of the English Channel group. While there was no significant difference in haplotype diversity between the English Channel and Brittany populations $\left(0.85 \pm 0.04 \leqslant h_{\mathrm{e}-\mathrm{HAP}} \leqslant 0.88 \pm 0.02\right)$, nucleotide diversity was two-fold lower within the latter group $\left(\pi=0.0031 ; t\right.$-test $\left.=1.227^{* * *}, P \leqslant 0.001\right)$ after exclusion of the Morlaix individual presenting a 'Channel' haplotype. The AMOVA analysis of molecular variance (Table 5) reveals a significant level of genetic heterogeneity between the two groups $\left(\mathrm{F}_{\mathrm{CT}}=0.123 ; P=0.001\right)$. Among population variation in both groups only accounted for $0.04 \%$ (English Channel) and $1.03 \%$ (Brittany) of the total variance (in terms of $\mathrm{F}_{\mathrm{ST}}$ ), thus 
possibly reflecting genetic homogeneity within each group. This is further reflected in the neighbour-joining tree, which reveals two distinct clades (Figure 2) separating the populations of the English Channel (clade 1) from those present along the coasts of Brittany (clade 2) (also see map of the distribution of haplotype frequencies, Figure 3). Relative rate constancy of a molecular clock was not rejected at 5\% significance level, thereby allowing estimates of the time of divergence between the two clades.

Limited divergence was found within each clade $\left(D_{\mathrm{AVG}}=0.7\right.$ and $0.3 \%$ respectively). Only Gravelines and Great Western Bay were significantly isolated from each other $\left(\mathrm{F}_{\mathrm{ST}}=0.07 ; P=0.018\right)$. The only clade 1 haplotype present in the Morlaix population was excluded from further analysis as it was one of the most common haplotype present in the Channel (HAP4; see Figure 3) and divergence between the two clades was high $\left(D_{\mathrm{AVG}}=16.4 \%\right)$. As a comparison, the average distance between $P$. koreni and the congeneric species $P$. auricoma is about $27 \%$ based on Kimura-2 parameter. As divergence was very deep, network picturing of haplotype relationships were calculated and drawn separately for each clades. The haplotype networks (Figure 4) were based on the 55 and 26 haplotypes present in clades 1 and 2, respectively (ie none was shared between the clades). Within clade 1, two groups of haplotypes were revealed in the network and which were shared across the sampled populations of the Channel. This was further confirmed with mismatch distribution of pairwise nucleotide differences where a bimodal topology was observed for all populations (Figure 5). Tajima's $D$ values were not significant and ranged from -1.49 to +1.12 . On the contrary, the curves generated for clade 2 populations of the Brittany coast were unimodal and coincided with a clustering of haplotypes into one group (Figure 4). Conversely, Tajima's $D$ was negative $(-2.01<D<-1.64)$ and deviated significantly from neutral expectations $(P$-value $<0.01-0.02)$ in three Brittany populations (Morgat, Lorient and Concarneau).

\section{Discussion}

Our results indicate a major phylogeographic break with 16\% divergence between the English Channel populations of P. koreni and those present along the coast of Brittany, and which appears to be associated with a marine biogeographic boundary along the north-western Brittany coast. The break in the spatial distribution of both mitochondrial haplotypes and enzymatic allele frequencies was not attributable to the presence of $P$. auricoma in the Brittany populations as individuals of this species were singled -out on the basis of (1) tube morphology and (2) diagnostic alleles at two enzyme loci (Pgi and $M d h$ ). In addition, when P. auricoma was used as an outgroup, the level of divergence $\left(D_{\mathrm{AVG}}=27 \%\right)$ was far beyond that observed between the two P. koreni clades. Although Brittany and English Channel populations of $P$. koreni were thought to belong to one species, the observed deep sequence divergence with fixed haplotype differences and the inversion of allele frequencies at two enzyme loci suggests potential cryptic or sibling species. Other arguments in favour of crypticism include the fact that microsatellite markers developed from Baie de Seine individuals (Weinmayr, 
Table 4 P. koreni. Correlation of homologous alleles between individuals within populations $\left(\mathrm{F}_{\mathrm{IS}}\right)$ for all variable loci

\begin{tabular}{|c|c|c|c|c|c|c|c|}
\hline & Rye Bay & Gravelines & Baie de Seine & Mont $S^{T}$ Michel & Morgat & Concarneau & Lorient \\
\hline Lap & -0.087 & -0.168 & 0.204 & 0.180 & 0.034 & 0.251 & -0.077 \\
\hline$M d h$ & -0.059 & 0.000 & -0.042 & - & -0.130 & $0.501^{* * *}$ & -0.256 \\
\hline$M e$ & 0.346 & 0.166 & -0.030 & -0.124 & $0.693^{* * *}$ & $0.914^{* * * *}$ & $0.944^{* * *}$ \\
\hline Mpi & 0.248 & $0.382^{* * *}$ & 0.092 & 0.086 & $0.249^{*}$ & $0.291^{* *}$ & $0.347^{*}$ \\
\hline$P g i$ & 0.222 & -0.073 & 0.300 & 0.153 & $0.490^{* *}$ & $0.635^{* * *}$ & $0.473^{* *}$ \\
\hline Pgm & 0.096 & -0.207 & 0.227 & $0.421^{*}$ & 0.115 & $0.413^{*}$ & $0.426^{*}$ \\
\hline Multilocus average & 0.159 & $0.139^{* *}$ & 0.145 & 0.156 & $0.264^{* * *}$ & $0.337^{* * *}$ & $0.477^{* * *}$ \\
\hline
\end{tabular}

Tests of significance were performed with Genepop 3.3 (Raymond and Rousset, 1995) (significance levels after sequential Bonferroni correction). ${ }^{*} P<0.05 ;{ }^{* *} P<0.01 ;{ }^{* *} P<0.001$.

Table $5 \mathrm{~F}_{\mathrm{ST}}-$ based hierarchical AMOVA between the 'English Channel' and 'Brittany coast' groups of $P$. koreni for both allozymes and mtCOI.

\begin{tabular}{|c|c|c|c|}
\hline Source of variation & Percent variation & Fixation indices & P-value \\
\hline \multicolumn{4}{|l|}{ Allozymes } \\
\hline Among groups & 0.18 & $\mathrm{~F}_{\mathrm{CT}}=0.029$ & 0.032 \\
\hline Among populations within groups & 0.95 & $\mathrm{~F}_{\mathrm{SC}}=0.043$ & 0.000 \\
\hline Within populations & 98.87 & $\mathrm{~F}_{\mathrm{ST}}=0.072$ & 0.000 \\
\hline \multicolumn{4}{|l|}{$\mathrm{MtCOI}$} \\
\hline Among groups & 12.30 & $\mathrm{~F}_{\mathrm{CT}}=0.123$ & 0.001 \\
\hline Among populations within groups & 0.13 & $\mathrm{~F}_{\mathrm{SC}}=0.001$ & 0.404 \\
\hline Within populations & 87.60 & $\mathrm{~F}_{\mathrm{ST}}=0.124$ & 0.000 \\
\hline
\end{tabular}

'English Channel': RB, GR, BS, MSM; 'Brittany coast': MRL, MO, CC, LO.

Table 6 P. koreni. Pairwise $\mathrm{F}_{\mathrm{ST}}$ values based on data for six enzymatic loci for all samples

\begin{tabular}{|c|c|c|c|c|c|c|}
\hline Populations & Rye Bay & Gravelines & Baie de Seine & Mont $S^{T}$ Michel & Morgat & Concarneau \\
\hline Gravelines & 0.007 & & & & & \\
\hline Baie de Seine & -0.003 & $0.019^{* *}$ & & & & \\
\hline Mont $S^{\mathrm{T}}$ Michel & 0.020 & $0.015^{* *}$ & 0.010 & & & \\
\hline Morgat & $0.015^{*}$ & $0.009^{*}$ & 0.007 & 0.010 & & \\
\hline Concarneau & $0.077^{* * *}$ & $0.071^{* * *}$ & $0.062^{* * *}$ & $0.075^{* * *}$ & $0.053^{* * *}$ & \\
\hline Lorient & $0.065^{* * *}$ & $0.157^{* * *}$ & $0.077^{* * *}$ & $0.124^{* * *}$ & $0.082^{* * *}$ & $0.050^{* * *}$ \\
\hline
\end{tabular}

${ }^{*} P<0.05 ;{ }^{* *} P<0.01 ;{ }^{* * * P}<0.001$. Tests of significance were performed with Genepop 3.3 (Raymond and Rousset, 1995) (significance levels after sequential Bonferroni correction).

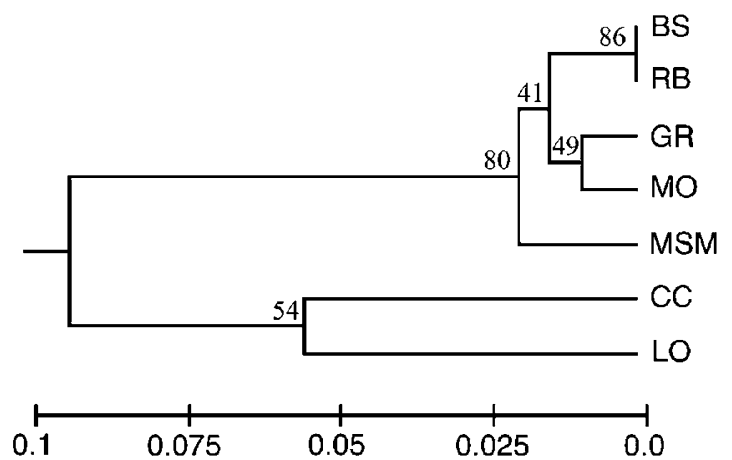

Figure 1 UPGMA tree showing the relationship between populations of $P$. koreni based on allozyme data using Reynolds et al's (1983) distance. Bootstrap values were estimated from 1000 replications.

1999) fail to amplify those from the Brittany clade (MT Jolly, personal observation), and that the data support the concept of allopatric relationships within cryptic radiations (see Wilke and Pfenninger, 2002 and references within). Only partial sympatry occurs at Morlaix and which needs to be investigated further to test for reproductive isolation between clades. However, this one sympatric population might just be the result of random unidirectional dispersal events (from MSM towards MRL) rather than long-term stability within the population.

Although estimates of the evolutionary rate of the mtCOI gene vary between taxa (Chevaldonné et al, 2002, even with the highest mutation rate $r \leqslant 2.2 \% \mathrm{Myr}$ (Knowlton et al, 1993), estimates of the time of divergence $(T \geqslant 3.7$ Mya) predate the Pleistocene period and the formation of the English Channel. Assuming that the time of divergence between the two clades predates the Pleistocene era would indicate that divergence was not the direct result of a geographic barrier produced by Brittany after the formation of the English Channel during the last interglacial some 9000 ya (Smith, 1989; Lambeck, 1997). The two entities would have emerged at a time when sea levels were low and where the present distribution of the species was very different. Yet, if we accept the concept of allopatric relationships within cryptic radiations, one species would have taken a more northern distribution than the other. One plausible scenario, which is in accordance with the presence of two groups of haplotypes and the significantly higher 


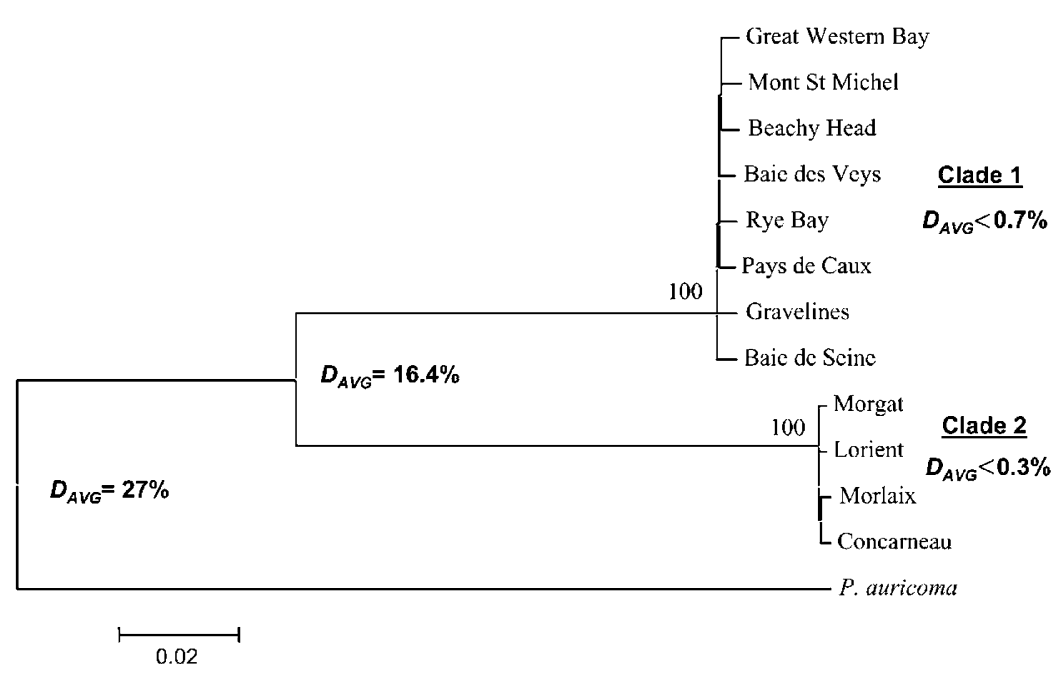

Figure 2 Neighbour-joining tree showing the relationship among COI haplotypes of $P$. koreni using Kimura-2 parameter distance method (Kimura, 1980). Bootstrap values were estimated from 1000 replications. $D_{\text {AVG }}$ is the average distance between two clades using the same distance method.

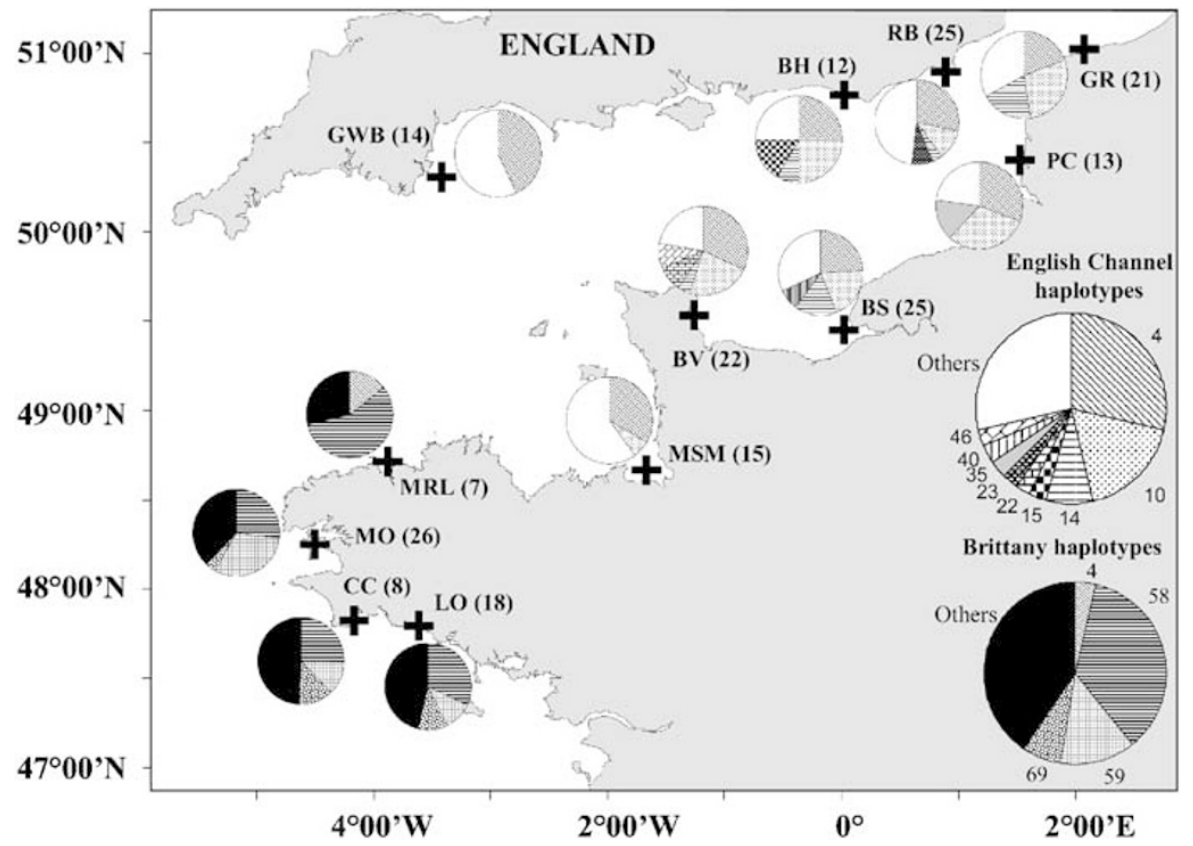

Figure 3 Map showing the distribution of COI haplotype frequencies across 12 sampled populations of $P$. koreni along the coasts of Brittany and the English Channel. Site abbreviations are as in Table 1. Numbers of samples per population $(N)$ are within parentheses. 'Others' represent haplotypes with less than $6 \%$ frequency in each population.

nucleotide diversity in the Channel group (see discussion below), may be that the more northernly distributed species had a wider range and colonised the English Channel from more than one area. First, via the western approaches of the English Channel between the end of the 'Last Glacial Maximum' (LGM) (circa 19 kya) and the 'Younger Dryas' cold phase (12.9-11.5 kya) during which the English Channel was partly open to the sea in the west (Lambeck, 1997) and where continuous permafrost was located above $55^{\circ} \mathrm{N}$ (Renssen and Vandenberghe, 2003). Second, via the North Sea, after the catastrophic opening of the Dover Straights in the late Pleistocene (some $10 \mathrm{kya}$ ) when a great volume of water spilled out of the North Sea across the emerged eastern and central portions of the Channel (Smith, 1989). Subsequently, the two differentiated populations could have made secondary contact after the formation of the Channel and which would have also been facilitated by the rise in water levels following the retreat of the ice sheets and the setting up of holocene marine currents. As the palaeoshorelines were approaching their present locations in Brittany and the Cherbourg coast by 8000 ya (Lambeck, 1997), the range of the more southernly distributed species was restricted by the pattern of holocene marine currents still maintained today in the western province of the English Channel. This is in accordance with hydrodynamic modelling of the potential larval dispersal of $P$. koreni (Ellien, 2001) using the model of Salomon and 

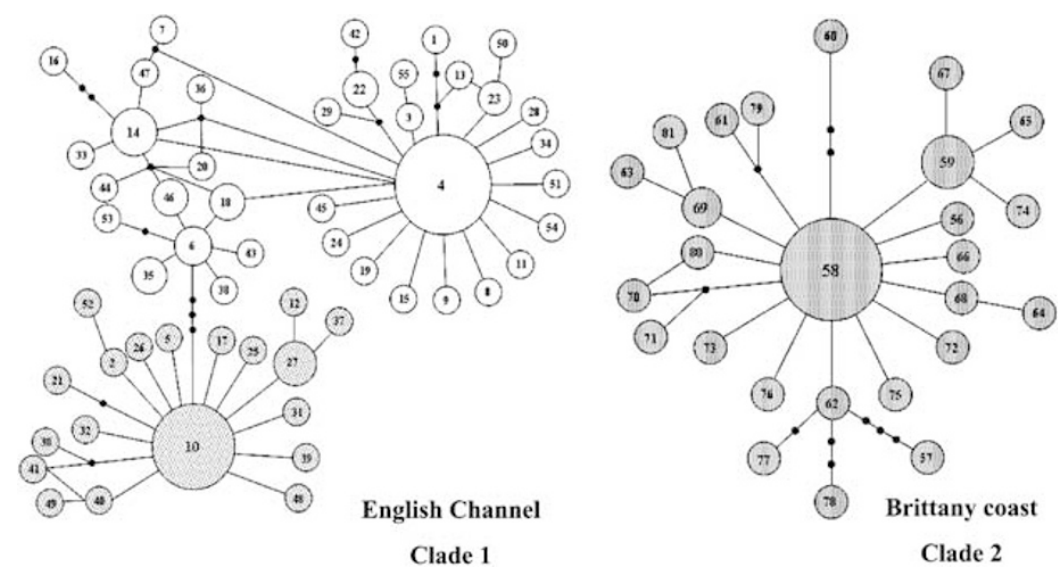

Figure 4 Haplotypic networks showing the evolutionary relationships between mitochondrial haplotypes of the English Channel and Brittany group of populations (clades 1 and 2, respectively). Circles represent haplotypes, with the area of each circle representative of the frequency with which it occurred in the total sample. Black dots represent hypothetical haplotypes not detected in the survey.
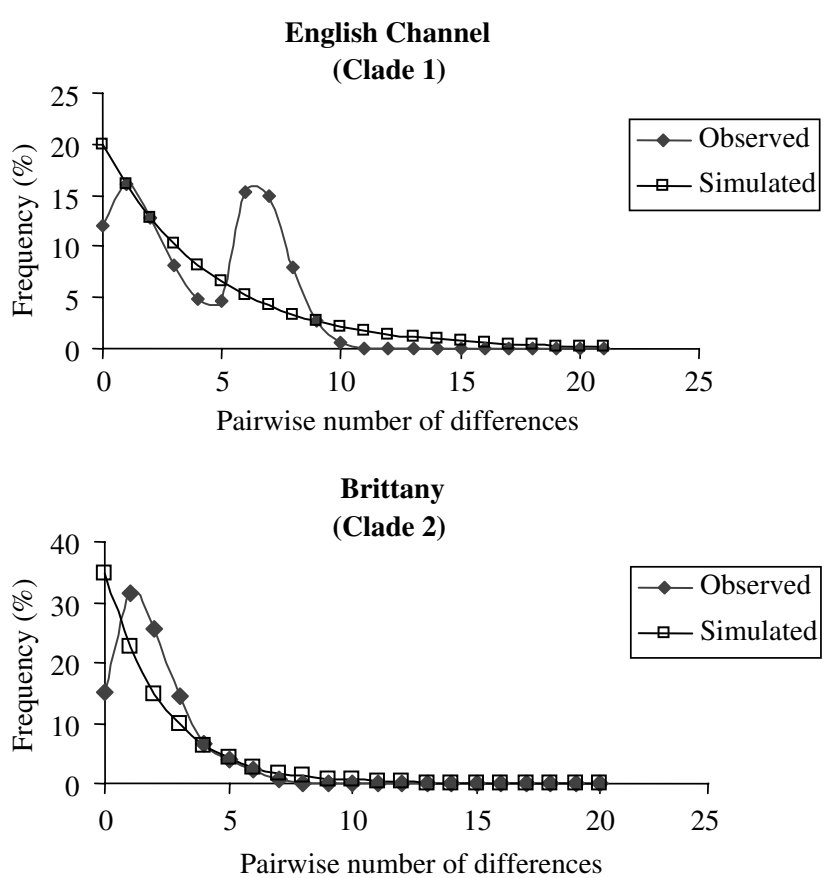

Figure 5 Observed and simulated match-mismatch curves under constant population size, generated for both the English Channel and Brittany populations of P. koreni.

Breton (1993), in which wind-driven currents may only favour larval export from the south to the north coast of Brittany.

In addition to the deep genetic break, there are some finer-scale patterns of differentiation within both Channel and Brittany populations, which may correspond to both Pleistocene habitat fragmentation or to the effects of contemporary gene flow and natural selection.

Within the English Channel group, the haplotype network reveals at least two groups of haplotype shared across all populations (except in GWB but probably due to sampling drift), no significant $F_{\text {IS }}$ (except for GR but only at the Mpi locus), no significant pairwise $\mathrm{F}_{\mathrm{ST}}$ values for sequence data (except between GR and GWB) and bimodal mismatch curves with nonsignificant values of Tajima's D. This suggests that populations of the English Channel are in a relatively stable state of panmixia. The fact that all populations of the Channel share the two most common clade 1 haplotypes is likely to have resulted from a secondary contact between differentiated populations (historic admixture) after each most common haplotype evolved separately in two distinct areas. Such areas could have served as temporary refugia during the LGM (23-19kya) where local diversification would have allowed for the separate evolution of the two most common haplotypes and from which animals have subsequently dispersed and intermingled. Potentially, small northern ice-free refugia could have existed in the northern North Sea area and in small localities along the coast of Scotland and Norway (Luttikhuizen et al, 2003). Additional sampling from these areas should confirm this. Within the Channel, some contemporary restriction on gene flow is revealed. For instance, the occurrence of unique haplotypes in the populations of Beachy Head and of the Pays de Caux most likely suggests that dispersal on either side of the populations is hampered probably because local hydrodynamism favours retention of larvae. Our results also support the hypothesis of an east-west separation of populations on either side of the Pointe du Cotentin, but only when the Morgat population is excluded.

We observed a close genetic similarity between Morgat and the English Channel populations for enzymatic data, whereas all COI sequences in this population were members of the Brittany clade. Clinal variations from north to south appear at three enzymes, which may either reflect the effects of natural selection, migratory events between populations belonging to the two clades (but without reproduction) or hybridisation between clades.

The populations of Brittany display completely opposite phylogeographic and demographic patterns than those within the English Channel. The fact that all populations show a substantial degree of genetic differentiation at allozyme loci but none at mtCOI sequences may correspond to the effects of recent habitat fragmentation around south Brittany. In addition, although nucleotide diversity was significantly lower 
than in the Channel, mean haplotype diversity remained high and similar, suggesting no recent bottlenecks in these populations. Rather, high haplotype diversity, low nucleotide diversity, unimodal mismatch distributions and significantly negative values of Tajima's $D$ (Tajima, 1989) could reflect population expansion along the Brittany coast during or following the Pleistocene. Diversification, as reflected by the relatively high percentage of private haplotypes within each population, would have followed due to habitat fragmentation. Interestingly, the highly significant $F_{I S}$ values observed at most allozyme loci in all Brittany populations seem to reflect recent contacts between genetically differentiated populations (ie Walhund effect).

Coastal currents may export larvae along the Brittany coasts. However, depending on the seasonal and interannual variability of current fields (see Lazure and Jegou, 1998 for hydrodynamic modelling), the average pattern may be modified yearly. During the reproductive period of P. koreni (April-June), there is an inversion of the circulation patterns that may favour connectivity between coastal populations. Alternatively, differential mortality of allochtonous larvae or reproductive asynchrony between bays could also be contributing to this genetic sorting.

Reproductive compatibility trials between the two $P$. koreni clades and detailed investigation at the morphological level (to confirm potential morphological crypticism) need to be performed experimentally to test the extent to which molecular phylogeny is reflecting species phylogeny. However, the fact that within the Brittany group highly significant $\mathrm{F}_{\mathrm{IS}}$ values are associated with the presence of only one group of haplotype could also indicate a change in the reproductive characteristics of $P$. koreni. This may be worth investigating in future studies, especially if reproductive isolation between the clades is revealed. Further sampling is needed in populations present along the Atlantic coast, Irish Sea and North Sea to investigate more closely the phylogeographic history of the two potential cryptic species of P. koreni and to delimit accurately putative refugia. In addition, the spatial patterns of the two taxa need to be investigated if the animals occur in areas of stable sympatry to test for any locally sharp separation of the two entities. This will enable us to address phylogeographic issues ranging from the causes of population genetic patterns (ancient or recent processes) to the objective identification of a cryptic/sibling species complex in P. koreni.

\section{Acknowledgements}

We are grateful to the crews of the NO 'Côte d'Aquitaine' and NO 'Côte de la Manche'. This work was cofinanced by the PNEC (Programme National d'Environnement Côtier), the IFB (Institut Français pour la Biodiversité) and supported by a PhD grant from the Brittany region. Laboratory equipment was provided by a special grant from the 'Bettencourt-Schueller' Foundation and sequencing facilities were provided by the 'Platforme Génopole Ouest' and 'Génomer' in Roscoff. Special thanks to Anne-Sophie Barnay and Stanislas Dubois for their help in the collection of the samples and to two anonymous referees for their significant contribution in the revision of the manuscript.

\section{References}

Apte S, Gardner JPA (2002). Population genetic subdivision in the New Zealand greenshell mussel (Perna canaliculus) inferred from single-strand conformation polymorphism analysis of mitochondrial DNA. Mol Ecol 11: 1617-1628.

Beaumont AR (1982). Geographic variation in allele frequencies at three loci in Chlamys opercularis from Norway to the Brittany coast. J Mar Biol Ass UK 62: 243-261.

Bierne N, Borsa P, Daguin C, Jollivet D, Viard F, Bonhomme F, David P (2003). Introgression patterns in the mosaic hybrid zone between Mytilus edulis and M. galloprovincialis. Mol Ecol 12: $447-461$.

Burton RS (1998). Intraspecific phylogeography across the Point Conception biogeographic boundary. Evolution 52: 734-745.

Chevaldonné P, Jollivet D, Desbruyères D, Lutz RA, Vrijenhoek RC (2002). Sister-species of eastern Pacific hydrothermal vent worms (Ampharetidae, Alvinellidae, Vestimentifera) provide new mitochondrial COI clock calibration. Cah Biol Mar 43: 367-370.

Clement M, Posada D, Crandall KA (2000). TCS: a computer program to estimate gene genealogies. Mol Ecol 9: 1657-1659.

Cox BC, Moore PD (2000) 6th ed. Biogeography: An Ecological and Evolutionary Approach, Blackwell Scientific Publications: London. 326pp.

Dinter WP (2001). Biogeography of the OSPAR Maritime Area. Federal Agency for Nature Conservation, Bonn: Germany. $167 \mathrm{pp}$

Dupont L, Jollivet D, Viard F (2003). High genetic diversity and ephemeral drift effects in a recent and successful introduced mollusc (Crepidula fornicata : Gastropoda). Mar Ecol Prog Ser 253: 183-195.

Ellien C (2001). Modélisation du transport larvaire en Manche et conséquences sur le recrutement d'invertébrés à cycle benthopélagique. Importance relative des processus biologiques et hydrodynamiques, Thèse de doctorat de l'Université Paris VI. 193 pp.

Folmer O, Black M, Hoeh W, Lutz R, Vrijenhoek R (1994). DNA primers for the amplification of mitochondrial cytochrome oxidase subunit 1 from diverse metazoan invertebrates. Mol Mar Biol and Tech 3: 294-299.

Goudet J (1995). FSTAT (vers. 1.2): a computer program to calculate F-statistics. J Heredity 86: 485-486.

Hall TA (1999). BioEdit: a user-friendly biological sequence alignment editor and analysis program for Windows 95/98/ NT. Nucleic Acids Symp Ser 41: 95-98.

Holthe T (1978). The zoogeography of the Terebellomorpha (Polychaeta) of the northern European waters. Sarsia 63: 191-198.

Irlinger JP, Gentil F, Quintino V (1991). Reproductive biology of the polychaete Pectinaria koreni (Malgrem) in the Bay of Seine (English channel). Ophelia Suppl 5: 343-350.

Jolly MT, Viard F, Weinmayr G, Gentil F, Thiébaut E, Jollivet D (2003). Does the genetic structure of Pectinaria koreni (Polychaeta: Pectinariidae) conform to a source-sink metapopulation model at the scale of the Baie de Seine? Helgol Mar Res 57: 238-246.

Kimura M (1980). A simple method for estimating evolutionary rate of base substitutions through comparative studies of nucleotide sequences. J Mol Evol 16: 111-120.

Knowlton N, Weigt LA, Solórzano LA, Mills DK, Bermingham E (1993). Divergence in proteins, mitochondrial DNA, and reproductive compatibility across the Isthmus of Panama. Science 260: 1629-1632.

Kumar S, Tamura K, Jacobsen IB, Nei M (2001). Molecular Evolutionary Genetics Analysis Software, Arizona State University: Tempe, USA.

Lambeck K (1997). Sea-level change along the French Atlantic and Channel coasts since the time of the Last Glacial Maximum. Palaeogeol Palaeoclim Palaeoecol 129: 1-22. 
Langella O (2002). Population 1.2.28. Logiciel de génétique des populations. Laboratoire Populations, génétique et évolution, CNRS UPR 9034, Gif-sur-Yvette, http://wwwcnrs-gif.fr/ pge/.

Lazure P, Jegou AM (1998). 3D modelling of seasonal evolution of Loire and Gironde plumes on Biscay Bay continental shelf. Oceanol Acta 21: 165-177.

Luttikhuizen PC, Drent J, Baker AJ (2003). Disjunct distribution of highly diverged mitochondrial lineage clade and population subdivision in a marine bivalve with pelagic larval dispersal. Mol Ecol 12: 2215-2229.

Nei M (1987). Molecular Evolutionary Genetics, Columbia University Press: New York.

Pasteur N, Pasteur G, Bonhomme F, Catalan J, Britton-Davidan J (1987). Manuel technique de génétique par électrophorèse des protéines, Lavoisier, Paris, Technique \& Documentation.

Pingree RD, Pugh PR, Holligan PM, Forster GR (1975). Summer phytoplankton blooms and red tides along tidal fronts in the approaches to the English Channel. Nature 258: 672-677.

Raymond M, Rousset F (1995). GENEPOP (version 1.2): population genetic software for exact tests and ecumenicism. J Heredity 86: 248-249.

Reeb CA, Avise JC (1990). A genetic discontinuity in a continously distributed species: mitochondrial DNA in the American oyster, Crassostrea virginica. Genetics 124: 397-406.

Renssen H, Vandenberghe J (2003). Investigation of the relationship between permafrost distribution in NW Europe and extensive winter sea-ice cover in the North Atlantic Ocean during the cold phases of the Last Glaciation. Quaternary Sci Rev 22: 209-223.

Reynolds J, Weir BS, Cockerham CC (1983). Estimation of the coancestry coefficient: basis for a short-term genetic distance. Genetics 105: 767-779.

Rozas J, Rozas R (1999). DnaSP version 3: an integrated program for molecular population genetics and molecular evolution analysis. Bioinformatics 15: 174-175.
Saavedra C, Zapata C, Alvarez G (1995). Geographical patterns of variability at allozyme loci in the European oyster Ostrea edulis. Mar Biol 122: 95-104.

Salomon JC, Breton M (1993). An atlas of long term currents in the Channel. Oceanol Acta 16: 439-448.

Schneider S, Roessli D, Excoffier L (2000). Arlequin (V2.0): Software for Population Genetics Data Analysis Genetics and Biometry Laboratory, Department of Anthropology, University of Geneva: Geneva.

Schulze ST, Rice SA, Simon JL, Karl SA (2000). Evolution of poecilogony and the biogeography of North American populations of the polychaete Streblospio. Evolution 54: 1247-1259.

Smith AJ (1989). The English Channel - by geological design or catastrophic accident? Proc Geol Ass 100: 325-337.

Tajima F (1989). Statistical method for testing the neutral mutation hypothesis by DNA polymorphism. Genetics 123: 585-595.

Weinmayr G (1999). Apports des marqueurs microsatellites à l'étude de la dispersion réelle en Manche d'espèces d'Annélides Polychètes à cycle benthopélagique, Thèse de Doctorat, Université Paris VI. 172pp.

Weir BS, Cockerham CC (1984). Estimating F-statistics for the analysis of population structure. Evolution 38: 1358-1370.

Wilding CS, Beaumont AR, Latchford JW (1997). Mitochondrial DNA variation in the scallop Pecten maximus (L.) assessed by a PCR-RFLP method. Heredity 79: 178-189.

Wilke T, Pfenninger M (2002). Separating historic events from recurrent processes in cryptic species: phylogeography of mud snails (Hydrobia spp. Mol Ecol 11: 1439-1451.

Williams ST, Benzie JAH (1998). Evidence of a biogeographic break between populations of a high dispersal starfish: congruent regions within the Indo-West Pacific defined by colour morphs, mtDNA and allozyme data. Evolution 52: 87-99. 